\title{
OliGreen Dye
}

National Cancer Institute

\section{Source}

National Cancer Institute. OliGreen Dye. NCI Thesaurus. Code C158434.

A proprietary green-fluorescent nucleic acid stain for quantitating oligonucleotides and single-stranded DNA (sSDNA) in solution. 